\title{
14th International Conference for Asia Digital Art and Design
}

\section{Yusup Sigit Martyastiadi}

Faculty of Art \& Design

Universitas Multimedia Nusantara, Indonesia

yusup.martyastiadi@umn.ac.id

Asia Digital Art and Design Association and Universitas Multimedia Nusantara, Indonesia held an international conference on art and design based on digital technologies on 1 - 2 November 2016. The conference held at Santika Hotel, Seminyak Bali, Indonesia. Sixtytwo scholars from various disciplines as art \& design to information technology convened and discussed the subject from various angles. The papers were covering various facets of research and practice on digital arts and designs. Papers were organised into topical areas, such as 'Digital System \& Service', 'Digital Museum', 'Media Art \& Interactive System', 'Virtual Reality', 'History, Theory \& Analysis', 'Algorithm', 'Game \& Gamification', 'Digital Content', 'Visual Effects'. They were spread across nine parallel sessions and one poster $\&$ demo core session. The centre of interest was the innovative, high-quality results and trials in arts and designs based on digital technologies.

There were two keynote topics on the conference. The first keynote was Yoichiro Kawaguchi; he is a Professor of the University of Tokyo and Japanese CG Artist since 1975 with phenomenal artwork, which called 'Growth Model'. He presented his reflection on computer graphic and multi-media arts from the vantage point of his own 40 years of working with them. The presentation titled 'Art and Self-organization'. He pointed that creative things should be separated from habits and tendency using tools which created in advance. Artists cannot let themselves on the software as a tool to push the creativity. Independence and originality should be the core of artistic creativity. His artworks were based on living things, which were created under a quasi-reconstruction method of the natural laws of the world. The artwork forms shaped and coloured according to the natural world and the cosmos. Kawaguchi stated "The enlargement of those realms of existence will certainly render a moulding cut off from the framework of earth or mankind possible. This will come to question its main constituent in the very process of selecting various subjects. Consequently, the way of existence of the object itself is already a product of conception, which is not cut off at all from the artistic qualities from which it should be separate. The very laws themselves concerning form have arisen and grown, creating their own present system which is self-propagating. In other words, the process has hypothesized something which retains energy within. It is something which has advanced one step beyond a simulation of a cross-section of the natural world. It is an approach to nature in another sense" (ADADA, 2016). 
The second central speaker was Daniel Harjanto; he is one of the founders of PT. Bali Animasi Solusi Ekakarsa, an animation studio with one important mission; to produce competent animation experts in Indonesia. As a Technical Director at BASE Animation, he involved in the production process of many projects; be it for feature length animated film or animated TV serials. There are shortlists of animated film projects, which Daniel contributed in, such as Meraih Mimpi (Sing to the Dawn), Tatsumi, Garfield TV Series, Franklin and Friends, Dr. Contraptus, Octonauts, Peter Rabbit, Sonic Boom. In his presentation titled 'Animation as a new Creative Industry in Indonesia', Daniel Harjanto described the development of animation industry in Indonesia, which is newest promising in creative sector. He explained some Indonesian small-scale animation studios that collaborate with some international animation studios in some projects. The main point was transfer knowledge and production behaviour adaptation from bigger studios (existing international animation studio). They need to create and modify their production pipelines to be more effectively and efficiently meet the needs of their line of business. Once they adapt more advanced technology, more works can be created with significant results in quality and quantity. In addition, Daniel Harjanto stated that education also have responsibilities to empowers students as prospectus talents to learn how to think creatively, to understand how technology might support their creative works, and how it becomes the part of their creative process. Consequently, the Indonesia education is also a part of the creative industry development.

In parallel session day 1, there were some sessions that run in same time. Firstly, Digital System \& Service session discussed topics about 'Mood-based Procedural Music Generation Using Markov Chains', 'Relationship between perceived value in OmniChannel Shopping and repurchase intention', 'The Development of APISNOTE a Digital Sticky Note System for Information Straucturing - Case study into the innovation workshops at i.school The University of Tokyo', 'A Method for Automatic Generation of Pictorial Maps Using SNS', and 'Study of the Types and Characteristics of Channel Shift of Omni Channel Service'. At the same period, Virtual Reality session convened 'The Effect of Squash and Stretch Principle In 3D Character's Facial Wrinkles', 'Graphic User Interface On Virtual Reality Tour Scene Of SIMIGAPI', 'Visual storytelling using 3D immersive animation, Study case: News Television Explanatory', 'A Study on Virtual Reality Storytelling by Story Authoring Tool Algorithm', 'A Study on VR Game Interface based on Mobile HMD -Focusing on FPS Game-'.

Secondly, after lunch break, the parallel session continued with Digital Museum session topics, such as 'Animated Ramayana Story in Multiscreen Display Using Wayang Beber Visual Language', “'Bhuyakha”: Experimental Animated Documentary Installation about Endangered Freshwater Fish of Sentani Lake', 'Development of glocal culture contents utilizing an HMD : 'Muru in Wonderland', a VR content for children's experience of Gwangju', 'The Proposal for Personalized Service and Exhibition Model based on Audience Tendency in Virtual Museum', 'Digital Restoration Attempt on Jindeyuan Temple in Jakarta'. The next session was Media Art \& Interactive System, which discussed about 'A System for Generating Musical Score Indicating the Hitting Hand for Drum Performance', 'Taifurin: IT sound installation as a typhoon warning system', 'Breathing shelter-Relieve citizen pressure with the breath control', 'A Study of Digital Media Art Utilizing 2D 
Animation', 'Development and case study of a sensor platform system for media art and live performance using wireless microprocessor module TWE-LITE', 'Clock Light Design Based on Sunrise and Sunset Time'. At the same time, History, Theory \& Analysis session convened 'Animating History of Celebes Sea Region in 19th Century: Reviving Historical Context through Animation', 'Practice of Open Sharing at Yamaguchi Center for Arts and Media [YCAM]', 'Visual Persuasion on Bukalapak.com Online Video Advertisement', 'History of modern Korean typeface: Investigation and analysis of new Korean types (1876 1909)', 'A Study on Classification of User Onboarding Factors Using Service Blueprint (Focusing on mobile commerce applications)', 'A Study on Modern Alienation \& Ambivalence through Collection of Urban Inner Side'.

Parallel session day 2, after second keynote speaker presentation, session of Algorithm talked about 'Analysis of Artificial Flock Characters Moving Pattern based on Boid method', 'Medallion: 3D-printed Wall Plaques based on Procedural Modeling', 'Perception of impossible figures focusing on inconsistent rectangles', 'Toy which simulates group behavior with multidicple range sensors', 'A Study on Graphic Pattern Generation Software', 'Local Pressure Correction Model for Position Based Fluids'. In parallel, the session of Digital Content discussed 'The Supporting Method for Creating a Character Gaze Animation based on Viewer's Preference', 'The Halo Effect of Webtoon Characters on Consumers with a High Psychological Aversion to Advertisements: with a focus on webtoon PPL(Product Placement) marketing', 'An Adaptation of the Endangered Togutil Tribe's Local Wisdom into an Animation Character Design', 'Performance of Joshua A Short Film Through Curated Online Video Platform Viddsee', 'Colour implementation with Fauvism Style to Limited Amination Character "We Are Different Yet We Are Same”, 'Media Facades - Brand communication based on visual density'.

The second parallel session consisted two areas, first of all, Game \& Gamification session talked about 'Development and Verification of the game "Locomo de Balamingo"', 'Sidestep and Sneak peek: spatial actions in augmented reality games', 'Design Concept of Digital Visual Novel Based on Giri Kedaton History to Develop Tourism in Sunan Giri Museum', 'Environtment Design on 2D PC Puzzle Platformer Game ASCENDER', 'A Study of the Interaction Trend of PC MMORPG Linked App $\bigotimes$ Focusing on the Elements of User Motivation', 'From Techo-Gaia to Kala Isvara: Gamification on Introduction to ICT Development Course for Visual Art \& Design Students in 2013 - 2015'. The other room session discussed the main area of Visual Effects with sub-topics of 'Utilizing Traditional Watercolor Media for Backgrounds in Digital 2D Animation Pipeline', 'Research About the Causal Attributions of VFX Effects in Special Effects', 'The Research for Withering Plants Movie', 'The Application of Non-photorealistic Rendering to Create Low Poly Visual Style in 3D Animation "Balloon”, 'The Adaptation of Balinese Sculptures within The Visual Effect Elemen Desain of "Bali Strait Legend”, 'Battle Scene : 2D and 3D Animation Techniques Analysis in "The Rebuild of Evangelion”'.

There was also Poster \& Demo Core session, that involved nine studies, such as 'Observation with hearts and hands', 'Typhoon Soudelor: Comparing remotely-sensed data and Tweets', 'A GUI Movement System by Back-of-Device Interaction for OneHanded Operation on a Large Screen Smartphone', 'Unistroke Gesture on the Eye 
Tracking System', 'KOKYU: A Non-Contact Sensing System With A Scalable Sphere For Visualization Breathing', 'Dancing Mirror: An Interactive Installation for Discovery of Aesthetic in Motions', 'Development the Interactive Tonality Blending System and Artworks', 'Development and case study of a sensor platform system for media art and live performance using wireless microprocessor module TWE-LITE', 'Mood-based Procedural Music Generation Using Markov Chains'.

The selected papers of this conference published in International Journal of Asia Digital Art and Design, Vol. 21 No. 01, 2017, ISSN 2189-7441.

\section{REFERENCES}

Program Committee ADADA, (2016), Program Book ADADA 2016, 14th International Conference of Asia Digital Art And Design Association, Bali, Indonesia 